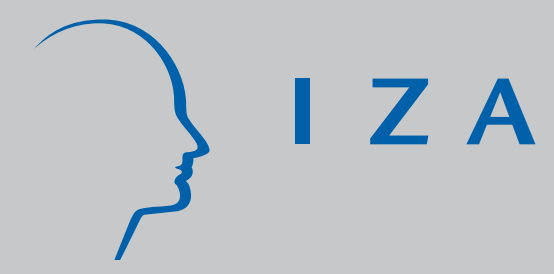

IZADP No. 1532

Moral Hazard and Cash Benefits in Long-Term Home Care

Bernard van den Berg

Wolter H.J . Hassink

March 2005 


\title{
Moral Hazard and Cash Benefits in Long-Term Home Care
}

\author{
Bernard van den Berg \\ University of Technology, Sydney \\ Wolter H.J. Hassink \\ Utrecht University \\ and IZA Bonn \\ Discussion Paper No. 1532 \\ March 2005
}

IZA

P.O. Box 7240

53072 Bonn

Germany

Phone: +49-228-3894-0

Fax: +49-228-3894-180

Email: iza@iza.org

\begin{abstract}
Any opinions expressed here are those of the author(s) and not those of the institute. Research disseminated by IZA may include views on policy, but the institute itself takes no institutional policy positions.

The Institute for the Study of Labor (IZA) in Bonn is a local and virtual international research center and a place of communication between science, politics and business. IZA is an independent nonprofit company supported by Deutsche Post World Net. The center is associated with the University of Bonn and offers a stimulating research environment through its research networks, research support, and visitors and doctoral programs. IZA engages in (i) original and internationally competitive research in all fields of labor economics, (ii) development of policy concepts, and (iii) dissemination of research results and concepts to the interested public.
\end{abstract}

IZA Discussion Papers often represent preliminary work and are circulated to encourage discussion. Citation of such a paper should account for its provisional character. A revised version may be available directly from the author. 


\section{ABSTRACT}

\section{Moral Hazard and Cash Benefits in Long-Term Home Care*}

This paper tests empirically for ex-post moral hazard in a system based on demand-side subsidies. In the Netherlands, demand-side subsidies were introduced in 1996. Clients receive a cash benefit to purchase the type of home care (housework, personal care, support with mobility, organisational tasks or social support) they need from the care supplier of their choice (private care provider, regular care agency, commercial care agency or paid informal care provider). Furthermore, they negotiate with the care supplier about price and quantity. Our main findings are the following. 1) The component of the cash benefit a client has no residual claimant on, has a positive impact on the price of care. 2) In contrast, the components of the cash benefit a client has residual claimant on, have no or a negative impact on the price of care. Both results point at the existence of ex-post moral hazard in a system of demand-side subsidies.

JEL Classification: $\quad 110$

Keywords: long-term care, cash benefits, consumer directed services, demand-side subsidies, direct payments, moral hazard

Corresponding author:

Wolter Hassink

Utrecht School of Economics

Utrecht University

Vredenburg 138

3511 BG Utrecht

The Netherlands

Email: w.hassink@econ.uu.nl

\footnotetext{
* A previous draft of this paper is presented at the fifth European Health Economics Conference in London. We would like to thank Xander Koolman, Wien Limburg, Erik Schut, Wynand van de Ven, Robert Welte, and Joshua Wiener for useful comments on an earlier draft of this paper, as well as the participants of a iBMG seminar in 2004 and the Fifth European Health Economics Conference 2004 in London for their discussion.
} 


\section{Introduction}

Although home care is a crucial element of long-term care, it has not received much attention in (health) economics (McKnight, 2004). Home care coverage by health insurance could involve moral hazard because most people utilize home care (Van den Berg, 2005). Cash benefits in long-term home care may strengthen such a risk of moral hazard, because a cash benefit provides clients, instead of health care agencies, the money to purchase the care. Because in the Dutch system clients are the residual claimant for part of the cash benefit, there is a unique opportunity to test for moral hazard due to cash benefits in long-term home care.

In many countries, long-term home health care is financed and organised through a system of supplier regulation, in which (social) insurers pay providers of care directly. Clients get their care in kind from regular agencies (regular care) without having to pay for it at the point of use (except for an income-related co-payment in some cases). Furthermore, they may purchase care on the commercial market from independent care suppliers (private care) or from commercial agencies (commercial care). On top of that, they may get informal care from relatives, friends and neighbours.

Some countries have developed alternative systems of demand-side subsidies in which clients get money (cash benefits also called consumer-directed services or direct payments) to purchase the care themselves instead of getting their care in kind (in which case they do not decide about the actual transaction of home care). There are no restrictions on the type of care nor on the care supplier the clients spend the cash benefit on. In this way, rather than providers of care, clients control their own health care in terms of quality, quantity and price. 
Countries that have experimented with cash benefits include Austria, France, Germany, the Netherlands, the United Kingdom, and the United States (US). For a detailed description of the programs see (Tilly et al., 2000) and (Tilly and Wiener, 2001). All of these countries are currently in transition from a system of supplier regulation towards demand-side subsidy, except for Austria, which has a system of demand-side subsidy only. Supplier-regulation dominates the long-term care sector in the Netherlands and the US ${ }^{1}$, while demand-side subsidy dominates in France and Germany (Tilly et al., 2000, p.2) and (Tilly and Wiener, 2001, p.2). Furthermore, the health care reform proposal of the Clinton administration dismissed in 1993 contained elements of demandside subsidy. It proposed to require all states to offer the option of demand-side subsidies to people with a disability (Tilly and Wiener, 2001).

Basically, demand-side subsidies have evolved differently across countries and states (in case of the US). Thus, in some countries clients get a cash benefit, whereas in other countries they receive a voucher. Policy makers are concerned for an uncontrolled rise of demand for long-term health care services and the concomitant rise of health care costs, especially in the case of cash benefits. (Tilly et al., 2000, p.4) Therefore, in all countries eligibility for cash benefits is based on strict rules. Thus, only people with a severe disability are eligible and there is a maximum to the number of people with a cash benefit, to the cash benefit a person may get, and to the total cash benefit budget.

Despite its increasing use and popularity in many countries, empirical knowledge about the effects of cash benefits in health care on price has been absent in economic literature so far. This paper attempts to fill part of this gap, by getting some empirical

\footnotetext{
${ }^{1}$ In the US, many states have experimented with demand-side subsidy, especially Arkansas, California, Colorado, Florida, Kansas, Maine, Michigan, New Jersey, Oregon, Washington, and Wisconsin
} 
evidence about the consequences of demand-side subsidies in the long-term home care market.

An important implication of a demand-side subsidy is that it could involve moral hazard. The Dutch institutional setting provides an unique opportunity to test for moral hazard because there is a distinction of the cash benefit between a part a client has residual claimant on and a part he has no residual claimant on. In the Dutch system of demand-side subsidy, the cash benefit consists of three components, for which the client has different rights about the unspent residual. The client has no residual rights on the first component, the personal budget, but he is the residual claimant of the lump sum, the second component, and the income-related co-payment, the third component. All three components together will be referred to as the cash benefit.

Because of the difference in residual claimancy right, clients may have different incentives to spend the cash benefit's components. This is ex post moral hazard ${ }^{2}$ because the client is no residual claimant of the personal budget (the first component). Ex post moral hazard means that consumers purchase more expensive care than they would purchase if they were the residual claimants, ceteris paribus.

The aim of this paper is to investigate whether the residual claimant component of the cash benefit has an upward effect on the price of care, ${ }^{3}$ ceteris paribus because of expost moral hazard.

In addition, in a system of demand-side subsidy, quality of care could be increased because of the larger potential of care suppliers and because of an increase in and Manning (2000). 
consumer's market power due to the cash benefit. However, problems of validity make it impossible to investigate empirically improvements in quality. For instance, from the client's perspective care provided by lower or unskilled care suppliers could be of a higher quality, although it may lead to care of a lower quality from a health care professional point of view, for example, measured in terms of education of the provider of care (Stiglitz, 2001). Quality of care is also experienced very subjectively among consumers of care. In this paper we abstract from a change in quality.

To address the research question, we will use information from a unique survey. The survey contains information on 301 clients with a cash benefit, for the sub-category nursing and caring. Next to the amount and types of care they purchase, the survey provides information on the price of care and the amount of the cash benefit (for each of the three components), the amount of care clients can legally claim (proxy for care needs), and information on scarcity in the care supply.

The outline of this paper is as follows. Section 2 describes the Dutch institutional context in more detail as well as the rules concerning cash benefits. Section 3 gives the empirical model to test for moral hazard in terms of price of care in a system of demandside subsidies. Section 4 describes the data set and Section 5 discusses the estimates, while Section 6 presents conclusions.

\section{Institutional setting}

Long-term care, which is an important part of the Dutch health care sector, can be distinguished into home care and institutional care. In what follows we will focus on

\footnotetext{
${ }^{3}$ In this paper, we distinguish hourly and monthly prices because some clients agree on hourly and some on monthly prices with their care suppliers. We will present regression results of hourly and monthly prices
} 
home care. Traditionally, the home care sector was based on supplier regulation. In this system, the client gets his care in kind through professional care suppliers from an agency, so-called regular care. The market of professional home care is regulated by means of entry barriers for new agencies and maximum prices determined by the government (CTG, in Dutch "College Tarieven Gezondheidszorg"). By means of entry barriers the government controls the quality of the care provided, for instance, by requiring educational standards for the employees of the care agencies.

Long-term home care is financed by means of compulsory social insurance, but there may be an additional income related co-payment. Consequently, a substantial part of regular care is free of charge to the client in the short run. Administration and payment are arranged among health care agencies and insurers. All insurers in a region handed voluntary over their implementation tasks (such as the purchase of care) to so-called regional care-offices (in Dutch "zorgkantoor"). In practice, the dominant player in the region executes the care office. Each region has an office, referred to as regional indication organ (RIO, in Dutch "Regionaal Indicatie Orgaan"), which determines independently the amount of regular home care an insured client may claim as a result of his health problems. Next to this regular care, clients are free to hire private care in the market from independent, private care providers on a commercial or non-commercial base, or from commercial agencies. Especially in case of housework there are many market alternatives for the regular care agencies. Often clients also get informal care from family or friends. About 750,000 informal care suppliers (the Netherlands has 16 million inhabitants) provide care for more than three months per year and for more than eight hours per week and 1.3 million informal care suppliers provide care for less than eight

separately. For convenience we do not distinguish them in the text of the paper. 
hours per week (Timmermans, 2003). About 1.7 million informal care suppliers provide care for less than three months per year.

For various reasons there has been a tendency in the long-term care sector from supplier regulation to demand-side subsidy. In the early 1990s, the main argument of interest groups was to achieve emancipation of clients with chronic diseases. Hence, they would control their own health care services instead of being dependent on health care professionals and their agencies. In the late 1990s, there arose the additional motives that demand-side subsidy would increase the quality of home care and that it would reduce the scarcity in health care.

Since 1996, there has been a transition from supply control towards demand-side subsidy in the Dutch home-care sector. Between 1996 and 2001, the transition was partial. Most clients received regular care in kind (supply control), but they could opt for a cash benefit (demand-side subsidy). Cash benefits covered a maximum of five percent of the total Dutch expenditures in long-term home health care. Table 1 shows that the annual number of cash benefits increased rapidly after the introduction in 1996 from 5,401 to over 48,000 in 2002 . To give an impression of the relative importance of cash benefits in the Dutch health care system, cash benefits accounted for 3.5 percent of the total expenditures in the sector nursing and caring in 1999. This sector accounts for about 20 percent of the long-term care sector. The long-term care sector accounts for 20 percent of the total annual health care expenditures of 36 billion euro.

\section{Table 1 here}


The cash benefit is the core of the system of demand-side subsidy. It consists of three components: (1) personal budget (In Dutch 'trekkingsrecht'), (2) lump sum, and (3) income-related co-payment. The personal budget is the part of the cash benefit that the client does not get directly. The Social Insurance Bank (SVB) ${ }^{4}$ manages the personal budget. A client can instruct the SVB to pay his care provider, but he has to justify the expenditures of this part of the cash benefit. ${ }^{5}$ The lump sum is used to compensate the client for transaction costs (overhead, unexpected costs, and cash payments) he makes in the very short run. Clients get the lump sum on their banking account, and they do not have to justify their spending afterwards. In 2001, the lump sum was 10 percent of the cash benefit with a maximum of 1,089 euro annually. Finally, there is an income-related co-payment. Appendix A contains a description of the scheme.

The cash benefit which consists of the three components is equal to the indicated need of home care converted in an amount of money. The size of the personal budget is equal to the indicated need of home care (which is converted into an amount of money), net of the income-related co-payment and the lump sum. The system leads to exogenous variation in the personal budget, since the co-payment is income related and the lump sum has a maximum.

Clients may have different attitudes as to how they spend each of the three components of the cash benefit. They may be more inclined to spend carefully the lump sum and the co-payment, as they may keep the remaining amount of money that has not

\footnotetext{
${ }^{4}$ The Social Insurance Bank is a social security agency.

${ }^{5}$ This was the actual situation when we collected the data between December 2001 and February 2002. From April 2003, clients get the personal budget on their bank account and manage it themselves. They have to justify their spending afterwards. Control occurs by means of random checks, since there were many complaints from clients about the way the SVB managed the personal budgets.
} 
been spent. In contrast, clients may be indifferent in their way of spending the personal budget, since they cannot claim the unspent residual. It may lead to moral hazard. ${ }^{6}$

The RIO determines the size of the cash benefit, using the indicated amount of care needed. In an interview with the client, the RIO determines how many hours of different care types (parts or products) per week or per month a client needs. The different products are skilled and unskilled housework, personal care, specialised personal care, nursing, and specialised nursing. A main distinction between unskilled and skilled housework is that the client is either able or unable to give housework tasks to the care supplier. For instance, when a client cannot manage his own household, he needs skilled housework which means that the house worker not just follows the client's instructions but also determines that certain tasks need to be done.

Cash benefits are distinguished into four sub-categories: Nursing and caring, Psychiatrically disabled, Mentally ill, and Physically disabled. Each of these categories has a different type of cash benefit. ${ }^{7}$ The categorization is made according to the client's health problems. For example, the sub-category nursing and caring is often used for elderly or people with a chronic disease who cannot care for themselves or for their household. The sub-category psychiatrically disabled differs also from the other three types with respect to the calculation of the amount of cash benefit. The largest subcategory is nursing and caring, which accounts for about 70 percent of the total number of cash benefits (see Table 1).

\footnotetext{
${ }^{6}$ Clients cannot claim the unspent residual of the personal budget, except $10 \%$ if the client also gets a cash benefit in the next period. Possible other savings are returned to the insurance company.

${ }^{7}$ The four sub-categories were mainly distinguished for bureaucratic reasons. Since 1 April 2003, the different types of cash benefit are integrated into one type of cash benefit.
} 


\section{Empirical model: Price of care in demand-side subsidy}

We will investigate the factors that influence price of care in a system of demandside subsidy. The size of the cash benefit (especially the personal budget part of the cash benefit) is determined by the care recipient's need for care. A higher budget simply means greater care needs. It could also imply the need for more specialised and therefore more expensive care. In our period of investigation, there were shortages in the supply of home care. Hence, we would expect prices to rise in a situation of excess demand. Furthermore, the price of care depends on the type of home care indicated. Our empirical analysis will control for all these influences (health status, type of care, composition of care and shortage of care). As the co-payment is income related, we will correct for household income as well.

Then, we will focus on the effect of the three components of the cash benefit (personal budget, co-payment, and lump sum) on price to test for moral hazard. All clients receive a cash benefit in the system, for which they may decide how to spend it on what type and amount of care.

The clients' incentives differ for different components of the cash benefit. Clients may keep both the unspent lump sum and the unspent income-related co-payment. For both components the incentive system may lead to lower prices, ceteris paribus. Clients are not allowed to keep the unspent part of the component of the cash benefit, viz. the personal budget. Consequently, a personal budget may lead to ex post moral hazard. With a higher personal budget, clients may consume care at higher prices compared with clients with a relatively smaller personal budget, ceteris paribus. We test for moral hazard by measuring the impact of the size of the personal budget on price, next to the effect of 
the co-payment and the lump sum. Since the co-payment is income related and the lump sum has a maximum, there is exogenous variation among the clients in the relative amount of the part of the cash benefit they are residual claimant on. Hence, the incentives to negotiate for a lower price of care differ among the clients as well.

The regression equation is a price equation. We specify the dependent variable as the logarithm of the mean price $(\mathrm{P})$, which is weighed for the different types of care received.

$$
\log \left(\mathrm{P}_{\mathrm{i}}\right)=\gamma_{1}{ }^{*} \log \left(\mathrm{PB}_{\mathrm{i}}\right)+\gamma_{2} * \log \left(\mathrm{CP}_{\mathbf{i}}\right)+\gamma_{3} * \log \left(\text { For }_{\mathbf{i}}\right)+\lambda^{\prime} \mathrm{X}_{\mathrm{i}}+\varepsilon_{\mathrm{i}} \mathrm{i}=1, \ldots, \mathrm{n}
$$

The three components of the cash benefit, the size of the personal budget, income-related co-payment and lump sum, are represented by the variables PB, CP and For (all of them are in logarithms). Clients have the residual claimancy right on CP and For and not on PB. $\gamma_{\mathrm{k}}, \mathrm{k}=1,2,3$, are parameters and $\lambda$ is a vector of parameters. $\mathrm{X}$ is a vector of control variables, which are age, gender, (the logarithm of) net monthly household income, marital status, education. Furthermore, we control for type of care (distinguished by housework (skilled and unskilled), personal care, specialised personal care, and nursing per week) and the availability of care (regular and commercial), which picks up any shortages in the supply of care. Finally, we control for the amount of care that the client needs, as indicated by the independent RIO. Hence, we correct for the client's health status.

With equation (1) we can test for moral hazard. A positive sign of $\gamma_{1}$ means that clients may pay a higher price when they are not the residual claimant of the unspent 
personal budget. In contrast, $\gamma_{2}$ and $\gamma_{3}$ are non positive, since clients are the residual claimant of the two remaining components of the cash benefit. Hence, there is an incentive to spend their money carefully.

\section{Data}

We used information from a data set of respondents with a cash benefit to estimate equation (1). We reached the respondents through Per Saldo, which is the Dutch association for people who receive a cash benefit. Between December 2001 and January 2002 , we sent a postal survey to 3,000 people with a cash benefit. 609 respondents with a cash benefit returned a completed survey. There are no reasons to assume that the members of Per Saldo are not representative for the whole population of clients with a cash benefit in The Netherlands in the period of our investigation. ${ }^{8}$

The data set gives detailed information on clients' cash benefits. In order to have a more or less homogenous group of clients with the same type of cash benefit, we used clients from the category Nursing and caring. 404 out of 609 respondents were clients with a cash benefit Nursing and caring. The net sample of clients with a cash benefit Nursing and caring consists of 301 respondents $^{9}$. We used the net sample in the empirical analysis.

Table 2 here

\footnotetext{
${ }^{8}$ Between 1996 and 1999 all clients were obliged to become a member of an association like Per Saldo. ${ }^{9} 172$ clients pay their care suppliers on an hourly basis and 129 on a monthly basis. Clients are free to agree on the payment with their care suppliers.
} 
Table 2 gives the descriptive statistics of the variables that were used as a control variable in the regression equation (1). There are no striking differences between the clients who pay their care recipients per hour or per month. The hourly price of care is on average 18.91 euro $^{10}$ and the mean monthly price is 1,401 euro. The monthly personal budget is about 1,240 euro, whereas the co-payment (about 118 euro) and the lump sum (about 150 euro) are substantially smaller. Clients paying their care suppliers on a monthly basis, spend on average 1,401.24 euro per month. This is 174.31 euro more than their monthly personal budget on which they do not have any residual claimant right. But the sum of their monthly personal budget, co-payment and lump sum is 1,488.86 euro. So, the clients spend on average 87.62 euro less on care than the care they need according to their indication. ${ }^{11}$ On average, the clients purchase around 10 hours of care per week. Table 2 gives the proportions of purchased care. This is because we wish to correct for composition effects in equation (1). To correct for the care needs of the care recipients, we use the indicated numbers of hours of care for the different care types, as determined by the independent agency. The number of indicated hours corrects for the health status of the client. For the various types of care, the indicated numbers of hours are on average around 5 (housework, skilled), 1 (housework, unskilled), 4.5 (personal care), 0.15 (specialised personal care), 2 (nursing), and 0.27 (specialised nursing). Note that the sum of these components is almost 13 hours a week, which is higher than the average number of hours purchased. The dummies indicating scarcity are defined as that

\footnotetext{
${ }^{10}$ We constructed the mean hourly price of home care as follows: Hourly price $=\Sigma_{z} \mathrm{p}_{\mathrm{z}} *\left(\mathrm{q}_{\mathrm{z}} /\left(\Sigma_{\mathrm{z}} \mathrm{q}_{\mathrm{z}}\right)\right.$, where $\mathrm{p}_{\mathrm{z}}$ is hourly price of care type $\mathrm{z}$ and $\mathrm{q}_{\mathrm{z}}$ is quantity of care of type $\mathrm{z}$.

${ }^{11}$ It is not possible to do the same calculations for clients paying their care suppliers on an hourly base, because there could be a lot of variation in the amount of supplied care per week while questions were just asked regarding the last week and not regarding the last month.
} 
a client attempts to get care from an agency for regular or commercial care, but that this type of care is not available yet.

\section{Estimates}

Here we present the estimates of equation (1). We are especially interested in the effects of the (logarithm of the) three components of the cash benefit on the (logarithm of the) price. Table 3 gives the estimated coefficients for the hourly and monthly price separately.

The clients are no residual claimant for the component personal budget.

Definitely, for this component the cash benefit has a positive impact on the price of care. For the equation estimated with hourly prices, the estimated coefficient on the logarithm of personal budget has a value of 0.19 and is significantly different from zero at the 1 percent level (for the estimate with monthly prices the coefficient becomes 0.66 ). Its value implies that a 1 percent increase in the personal budget leads to a 0.19 percent higher hourly price of care. Notice that the hourly price is 18.91 euro and the monthly personal budget is 1254.10 euro on average (Table 2).

For the two remaining components for which the client is a residual claimant we get the following estimation results. The estimated coefficients on the income-related copayment are statistically insignificant, while the coefficient on the lump sum is statistically insignificant in the hourly price equation but statistically significant and negative in the monthly price equation. Since we do not find positive coefficients for all three components jointly we can conclude that the estimates point at the prevalence of expost moral hazard. 
There is some evidence that for the hourly price equation the proportion of paid informal care and private care seems to have a downward effect on the hourly price, relative to the proportion of commercial care. For two types of care (specialised personal care and nursing in the hourly price equation) the number of indicated hours has an upward effect on the price. Two dummy variables indicating scarcity of care (regular and commercial care) seem to have no influence on the hourly prices paid.

\section{Conclusion}

In this paper we have investigated empirically the incentives regarding the negotiation about the price of care of clients with demand-side subsidies in long-term home care: A test for moral hazard. In the Netherlands, all respondents are compulsory insured for long-term home care. The specific Dutch institutional rules offered a unique possibility to test for ex-post moral hazard in terms of price of home care. We exploited the variation between respondents in the relative size of the part of the cash benefit they are residual claimant on, in which we corrected, inter alia, for the client's health status, the composition of care and the scarcity of health care supply. Hence, we could test whether the incentives to negotiate on the price of care differ between the part for which they are residual claimant on and the part for which they are no residual claimant on.

Our main conclusion is that with respect to the price of home care, we find indication of an upward effect from the component of the cash benefit for which the client is no residual claimant. In contrast, for the two remaining components we find no indication of an upward effect on the price of home care. These outcomes indicate that there is ex-post moral hazard in a system of demand side subsidy. 


\section{References}

Tweede Kamer der Staten Generaal, Meeting year 2002-2003. Cash benefits [in Dutch]. no. 25657 (26). The Hague.

McKnight, R., 2004. Home care Reimbursement, Long-term Care Utilization, and Health Outcomes. NBER Working Paper no. 10414. Cambridge, MA.

Stiglitz, J.E., 2001. The Contributions of the Economics of Information to Twentieth Century Economics. Quarterly Journal of Economics 115 (4), 1441-1478.

Tilly, J., Wiener, J.M., 2001. Consumer-Directed Home and Community Services: Policy Issues. no. Occasional Paper Number 44, The Urban Institute, Washington, DC.

Tilly, J., Wiener, J.M., Cuellar, A.E., 2000. Consumer-Directed Home and Community Services Programs in Five Countries: Policy Issues for Older People and Government. The Urban Institute, Washington, DC.

Timmermans, J.M.R., 2003. Mantelzorg : Vrij om te helpen (Informal care: On the help from and at informal care providers). Social and Cultural Planning Bureau of the Netherlands: The Hague.

Van den Berg, B., 2005. Informal care: an economic approach. Thesis Erasmus University Rotterdam.

Zweifel, P., Manning, W.G., 2000. Moral hazard and consumer incentives in health care. In: Culyer, A.J., Newhouse, J.P. (Eds.), Handbook of Health Economics. Elsevier Science: Amsterdam. 
Table 1: Annual number of cash benefits in the Netherlands 1996-2002

\begin{tabular}{|c|c|c|c|c|c|c|c|}
\hline & 1996 & 1997 & 1998 & 1999 & 2000 & 2001 & 2002 \\
\hline Nursing and caring & 4,000 & 6,045 & 7,184 & 9,408 & 16,282 & 26,753 & 34,544 \\
\hline Psychiatrically disabled & 1,400 & 1,500 & 3,101 & 3,641 & 6,195 & 9,164 & 11,197 \\
\hline Mentally ill & 1 & 100 & 125 & 120 & 141 & 608 & 2,203 \\
\hline Physically disabled & 0 & 0 & 0 & 0 & 0 & 57 & 95 \\
\hline Total & 5,401 & 7,645 & 10,410 & 13,169 & 22,618 & 36,582 & 48,039 \\
\hline
\end{tabular}

Source: (Tweede Kamer der Staten Generaal, Meeting year 2002-2003). 
Table 2: Descriptives of the data set: clients with a cash benefit for Nursing and caring

\begin{tabular}{|c|c|c|c|c|}
\hline \multirow[b]{2}{*}{ Variables } & \multicolumn{2}{|c|}{ Hourly price } & \multicolumn{2}{|c|}{ Monthly price } \\
\hline & Mean & $\begin{array}{l}\text { Standard } \\
\text { deviation of } \\
\text { mean }\end{array}$ & Mean & $\begin{array}{l}\text { Standard } \\
\text { deviation of } \\
\text { mean }\end{array}$ \\
\hline Hourly price of care (in euros) & 18.91 & 1.05 & - & \\
\hline Monthly price of care (in euros) & - & & $1,401.24$ & 227.99 \\
\hline Monthly personal budget (in euros) & $1,254.10$ & 108.10 & $1,226.93$ & 123.21 \\
\hline Monthly co-payment (in euros) & 119.42 & 9.99 & 118.66 & 11.14 \\
\hline Monthly lump sum (in euros) & 157.29 & 17.79 & 143.27 & 19.39 \\
\hline Age (in years) & 52.64 & 1.33 & 53.83 & 1.45 \\
\hline Dummy gender $($ woman $=1 ; \operatorname{man}=0)$ & 0.24 & 0.03 & 0.22 & 0.04 \\
\hline Net monthly household income (in Euros) & $1,603.01$ & 58.00 & $1,693.76$ & 66.36 \\
\hline Dummy married $($ married $=1 ;$ unmarried $=0$ ) & 0.68 & 0.04 & 0.69 & 0.04 \\
\hline Education (in years) & 12.66 & 0.26 & 13.12 & 0.30 \\
\hline \multicolumn{5}{|l|}{ Care supplier: } \\
\hline Proportion informal care & 0.62 & 0.03 & 0.56 & 0.03 \\
\hline Proportion regular care & 0.03 & 0.01 & 0.02 & 0.01 \\
\hline Proportion commercial care & 0.13 & 0.02 & 0.15 & 0.03 \\
\hline Proportion private care & 0.22 & 0.02 & 0.26 & 0.03 \\
\hline Hours of informal care (per week) & 7.40 & 1.02 & 6.78 & 1.21 \\
\hline Hours of regular care (per week) & 0.19 & 0.08 & 0.08 & 0.03 \\
\hline Hours of commercial care (per week) & 1.56 & 0.59 & 1.35 & 0.31 \\
\hline Hours of private care (per week) & 2.29 & 0.32 & 2.22 & 0.32 \\
\hline \multicolumn{5}{|l|}{ Type of care: } \\
\hline $\begin{array}{l}\text { Dummy housework (housework }=1 \text {; elsewhere }= \\
0 \text { ) }\end{array}$ & 0.98 & 0.01 & 0.97 & 0.02 \\
\hline $\begin{array}{l}\text { Dummy personal care (personal care }=1 \\
\text { elsewhere }=0 \text { ) }\end{array}$ & 0.69 & 0.04 & 0.67 & 0.04 \\
\hline $\begin{array}{l}\text { Dummy support with mobility (support with } \\
\text { mobility }=1 ; \text { elsewhere }=0 \text { ) }\end{array}$ & 0.68 & 0.04 & 0.68 & 0.04 \\
\hline $\begin{array}{l}\text { Dummy organisational tasks (organisational tasks } \\
=1 ; \text { elsewhere }=0 \text { ) }\end{array}$ & 0.47 & 0.04 & 0.46 & 0.04 \\
\hline $\begin{array}{l}\text { Dummy social support (social support }=1 ; \\
\text { elsewhere }=0 \text { ) } \\
\text { Indicated hours of care (per week): }\end{array}$ & 0.57 & 0.04 & 0.60 & 0.04 \\
\hline Hours of skilled housework & 5.47 & 0.43 & 4.87 & 0.48 \\
\hline Hours of unskilled housework & 1.01 & 0.20 & 1.11 & 0.21 \\
\hline Hours of personal care & 4.67 & 0.66 & 4.69 & 0.83 \\
\hline Hours of specialised personal care & 0.23 & 0.14 & 0.11 & 0.11 \\
\hline Hours of nursing & 2.25 & 0.45 & 1.66 & 0.37 \\
\hline Hours of specialised nursing & & & 0.27 & 0.19 \\
\hline Non-availability regular care $($ no $=0 ;$ yes $=1)$ & 0.17 & 0.03 & 0.16 & 0.03 \\
\hline Non-availability commercial care $($ no $=0 ;$ yes $=1)$ & 0.35 & 0.04 & 0.43 & 0.04 \\
\hline Hours of purchased care (per week) & 11.39 & 1.20 & 10.43 & 1.29 \\
\hline Number of clients & 172 & & 129 & \\
\hline
\end{tabular}


Table 3: OLS regression of equation (1) with robust standard errors; dependent variables: $\log$ (hourly price) and log (monthly price)

\begin{tabular}{|c|c|c|c|c|}
\hline $\begin{array}{l}\text { Dependent variable } \\
\text { Independent variables: }\end{array}$ & \multicolumn{2}{|c|}{$\begin{array}{l}\text { Log (hourly price) } \\
\text { Coefficient t-value }\end{array}$} & \multicolumn{2}{|c|}{$\begin{array}{l}\text { Log (monthly price) } \\
\text { Coefficient t-value }\end{array}$} \\
\hline Log cash benefit & 0.19 & 3.07 & 0.66 & 4.98 \\
\hline Log co-payment & -0.03 & -0.94 & 0.02 & 0.21 \\
\hline Log lump sum & 0.04 & 0.72 & -0.46 & -4.64 \\
\hline Age (in years) & 0.00 & -0.96 & 0.00 & 0.14 \\
\hline $\begin{array}{l}\text { Dummy gender } \\
(\text { woman }=1 ; \operatorname{man}=0)\end{array}$ & -0.01 & -0.06 & 0.45 & 1.50 \\
\hline Log household income & -0.03 & -1.03 & -0.13 & -1.52 \\
\hline $\begin{array}{l}\text { Dummy married } \\
\text { (unmarried }=1 ; \text { married }=0 \text { ) }\end{array}$ & -0.15 & -1.14 & -0.06 & -0.29 \\
\hline $\begin{array}{l}\text { Education (in years) } \\
\text { Care supplier: }\end{array}$ & \multicolumn{3}{|c|}{ Care supplier: } & 1.00 \\
\hline $\begin{array}{l}\text { Proportion informal care }(\text { ref. }=\text { proportion } \\
\text { commercial care) }\end{array}$ & -0.94 & -3.62 & -0.55 & -1.24 \\
\hline $\begin{array}{l}\text { Proportion regular care }(\text { ref. }=\text { proportion } \\
\text { commercial care) }\end{array}$ & -0.34 & -0.96 & -0.59 & -0.31 \\
\hline $\begin{array}{l}\text { Proportion private care }(\text { ref. }=\text { proportion } \\
\text { commercial care) } \\
\text { Type of care: }\end{array}$ & -0.44 & -2.04 & -0.19 & -0.51 \\
\hline $\begin{array}{l}\text { Dummy housework } \\
\text { (housework = 1) }\end{array}$ & -0.40 & -1.05 & -0.64 & -1.71 \\
\hline $\begin{array}{l}\text { Dummy personal care } \\
(\text { personal care }=1 \text { ) }\end{array}$ & -0.05 & -0.35 & -0.39 & -1.26 \\
\hline $\begin{array}{l}\text { Dummy mobility outside } \\
\text { (mobility outside }=1 \text { ) }\end{array}$ & -0.22 & -1.49 & -0.20 & -0.65 \\
\hline $\begin{array}{l}\text { Dummy organisational tasks } \\
\text { (organisational tasks }=1 \text { ) }\end{array}$ & -0.20 & -1.57 & -0.32 & -1.54 \\
\hline $\begin{array}{l}\text { Dummy social care } \\
(\text { social care }=1)\end{array}$ & -0.33 & -2.58 & -0.29 & -1.50 \\
\hline \multicolumn{5}{|l|}{ Indicated hours of care (per week): } \\
\hline Log indicated hours housework (skilled) per week & 0.08 & 1.34 & -0.17 & -1.47 \\
\hline Log indicated hours housework (unskilled) per week & 0.00 & 0.05 & 0.16 & 1.37 \\
\hline Log indicated hours personal care per week & 0.02 & 0.43 & 0.11 & 0.97 \\
\hline $\begin{array}{l}\text { Log indicated hours specialised personal care per } \\
\text { week }\end{array}$ & 0.29 & 2.14 & 0.40 & 2.34 \\
\hline Log indicated hours nursing per week & 0.25 & 3.72 & -0.07 & -0.38 \\
\hline Log indicated specialised nursing & & & -0.61 & -1.39 \\
\hline $\begin{array}{l}\text { Availability regular care } \\
(\text { yes }=1)\end{array}$ & -0.01 & -0.09 & -0.35 & -0.99 \\
\hline $\begin{array}{l}\text { Availability commercial care } \\
(\text { yes }=1)\end{array}$ & -0.10 & -0.70 & -0.21 & -1.01 \\
\hline Constant & 3.36 & 4.64 & 6.59 & 5.18 \\
\hline \multicolumn{5}{|l|}{ Standard error of regression } \\
\hline Number of clients & 172 & & 129 & \\
\hline $\mathrm{R}^{2}$ & 0.48 & & 0.53 & \\
\hline
\end{tabular}




\section{Appendix A}

\section{Cash benefit co-payments}

Income related co-payments cash benefits.

Your age is 65 years or older. Below, you will find below your maximum weekly copayment.

The co-payment will be calculated over the gross family income. The maximum hourly co-payment is $€ 4.60$.

\begin{tabular}{|l|c|c|}
\hline $\begin{array}{l}\text { Gross family income in } 2001 \text { in } \\
\text { categories }\end{array}$ & $\begin{array}{c}\text { Living together or } \\
\text { being married } \\
\text { Maximum per week }\end{array}$ & $\begin{array}{c}\text { Single person household } \\
\text { Maximum per week }\end{array}$ \\
\hline To $€ 12,526$ & $€ 2.20$ & $€ 2.20$ \\
\hline From $€ 12,526$ to $€ 16,182$ & $€ 3.00$ & $€ 7.00$ \\
\hline From $€ 16,182$ to $€ 18,270$ & $€ 10.80$ & $€ 25.80$ \\
\hline From $€ 18,270$ to $€ 20,880$ & $€ 29.60$ & $€ 40.00$ \\
\hline From $€ 20,880$ to $€ 25,056$ & $€ 59.00$ & $€ 103.80$ \\
\hline From $€ 25,056$ to $€ 40,718$ & $€ 89.60$ & $€ 129.80$ \\
\hline From $€ 40,718$ & $€ 118.00$ & \\
\hline
\end{tabular}

Your age is between 18 and 65 years. Below, you will find below your maximum weekly co-payment.

The co-payment will be calculated over the gross family income. The maximum hourly co-payment is $€ 4.60$.

\begin{tabular}{|l|c|c|}
\hline $\begin{array}{l}\text { Gross family income in } 2001 \text { in } \\
\text { categories }\end{array}$ & $\begin{array}{c}\text { Living together or being } \\
\text { married } \\
\text { Maximum per week }\end{array}$ & $\begin{array}{c}\text { Single person household } \\
\text { Maximum per week }\end{array}$ \\
\hline To $€ 15,138$ & $€ 2.20$ & $€ 2.20$ \\
\hline From $€ 15,138$ to $€ 19,316$ & $€ 3.00$ & $€ 7.00$ \\
\hline From $€ 19,316$ to $€ 22,970$ & $€ 10.80$ & $€ 25.80$ \\
\hline From $€ 22,970$ to $€ 26,624$ & $€ 29.60$ & $€ 40.00$ \\
\hline From $€ 26,624$ to $€ 31,844$ & $€ 59.00$ & $€ 103.20$ \\
\hline From $€ 31,844$ to $€ 48,550$ & $€ 89.60$ & $€ 129.80$ \\
\hline From $€ 48,550$ & $€ 118.00$ & \\
\hline
\end{tabular}

